\title{
Production of Omega 6 Probiotic by Isolation and Fermentation of Lactobacillus plantarum JR64
}

\author{
Lanjar Sumarno $^{1)}$, Djumali Mangunwidjaja ${ }^{2)}$, Anas M. Fauzi ${ }^{2)}$, Khaswar Syamsu ${ }^{2)}$, Nastiti Siswi Indrasti ${ }^{2)}$, \\ Bambang Prasetya ${ }^{3)}$ \\ ${ }^{1)}$ Biotech Center - BPPT, Gedung 630, Kawasan Puspiptek Serpong, Tangerang Selatan. \\ Telp.021-7563120, Fax:021-7560208.Email:lanjar64@biotek.bppt.go.id \\ ${ }^{2)}$ Agriculture Industrial Technology - IPB, Bogor \\ 3) Lembaga Ilmu Pengetahuan Indonesia (LIPI), Jakarta.
}

\begin{abstract}
Application of lactic acid probiotic bacteria in health food diversification currently is progressing rapidly. It is encouraged the study of searching the potential strains from local resources (Ponorogo Residence) namely noni fruits (badeg pace) and noni wine. Aims of this study were to perform the isolation, identification, and production of probiotic Lactobacillus sp. JR64 fermentation process as a producer of Omega-6 ( $\omega-6)$ lowering cholesterol and design of probiotic creamy product. Beginning stages of research was strains isolating and in-vitro testing, the best result were used in molecular identification technology development for the production of metabolites through the manipulation of environmental variation of glucose $20 \mathrm{~g} / 1,30 \mathrm{~g} / 1 \mathrm{and} 40 \mathrm{~g} / 1$ that influenced the substrate concentration of linoleic acid productivity. The result of new isolates isolation showed that isolates that obtained from noni wine, Lactobacillus plantarum JR64, was potential as probiotic condidate. The effieciency of fermentation substrates using Yx/s and $\mathrm{Yp} / \mathrm{s}$ in the exponential phase was the highest value for the fermentation of 24 hours of $\mathrm{Yx} / \mathrm{s} ; 17.03 \%$ and $\mathrm{Y} / \mathrm{s} ; 74.72 \%$, while the results of design and the best formulation for viability cells of lactobacillus plantarum probiotics JR64 was composed of 15 $\mathrm{g}$ and $50 \mathrm{~g}$ butter $15 \mathrm{~g}$ icing sugar as well as during storage of the refrigerant temperature was $8.92 \times 108 \mathrm{CFU} / \mathrm{ml}$.
\end{abstract}

[Key Words : Omega-6, Lactobacillus plantarum JR64, fermentation]

\section{INTRODUCTION}

Probiotics have been various defined according to the advantages. Probiotic is defined as microbial cell preparations or components of microbial cells that have a beneficial effect on health and life of its host. Lactic acid bacteria are the most widely used as probiotics may also improve the balance of intestinal flora if taken alive and in adequate amounts. Sugiyama et al. 1997 stated that the effect of linoleic acid (omega-6) decreased of rat blood serum cholesterol.

The spectrum use of lactic acid bacteria was encouraged the study of potential strain that comes from local resources. One of the explorations studies of local potential source was based on local belief of Ponorogo local people. They believe noni wine is benefit for their health. The study began by conducting a survey of 10 herbal wine drink sellers who regularly sell herbal medicine known as noni badeg pace. The wine is made by pressing of mature Morinda citrifolia. The palm sugar is added to the fruit extract and then allowed to stand for one night to produce the specific flavor and very sour taste. This condition allows the process of spontaneous fermentation of beneficial lactic acid bacteria. The lactic acid bacteria are able to grow at relatively acidic environment. The decline in $\mathrm{pH}$ during the fermentation process make other bacteria are not able to grow at a low $\mathrm{pH}$ environment.

The data obtained from that study was used as preliminary information for in vitro testing as probiotic condidate that includes testing the ability of growth at low $\mathrm{pH}$, antagonistic testing of topathogenic bacteria, testing its ability to grow on media containing bile salts. After found the potential isolates as probiotic then continue with microbe identification. Microbe identification aims to determine the species of isolates obtained and to study the properties of microbes as well as tracing the closest genetic relationship.

The results of molecular identification could be based the design of production process to obtain the metabolites target namely unsaturated fatty acids (omega-6). The results of this metabolite are influenced by the environment of metabolites during fermentation period. To obtain optimum results, metabolic manipulation is one of the available options in fermentation techniques. In this case, the modification of the microorganism metabolism by using the variable substrate concentration change the metabolism pathway that become into metabolic formation of linoleic acid (omega-6). Culture medium used is an important factor to obtain the good results of inoculums and cultivation.

The designed product in form of creams are expected to have broader functions need to be produced in the media formulations capable of producing high cell viability, where as to observe the function as probiotics was necessary to do further in vivo testing using experimental animals. In vivo testing was expected to be able to explore the potential of probiotics as the cholesterol decreased agent as Ponorogo local people belief.

The aims of this study were to conduct the isolation of microbes from badeg pace and noni, to conduct the fermentation process used Lactobacillus sp. JR 64 that was isolated from badeg pace and noni for producing probiotic produces Omega-6 $(\omega-6)$ and lower cholesterol. 


\section{MATERIALS AND METHODS}

The research was conducted at the Laboratory Center of Biotechnology Assessment, BPPT, Puspiptek, Tangerang. Lactobacillus sp. that was isolated from noni wine Ponorogo origin,East Java, Lactobacillus bulgaricus (FNCC41, UGM, pathogenic bacteria Escherichia coli ATCC 25922 and Staphylococcus aureus ATCC 25923 were used.

The chemicals used were MRS (De Mann, Rogosa Oxoid CM 0361), TSB (Tryptone SoyaBroth), Oxoid CM 0129, CMC (Himedia), Cat grams (Merck), Mueller Hinton Agar (Oxoid CM 0337), unsalted Butter (Orchid), bile salts (Oxoid), Icing Sugar, $0.2 \mathrm{~N} \mathrm{NaOH,} \mathrm{s}$ elenium tablets, concentrated $\mathrm{H}_{2} \mathrm{SO}_{4}, 0,05 \mathrm{~N} \mathrm{HCl}$, boric acid, $\mathrm{CaCO}_{3}, \mathrm{HCl}, \mathrm{BTB}$ indicator, $1 \%$ pp indicator, distilled water, $70 \%$ alcohol, cotton, and alumunium foil: Flow diagram of research stages were presented in Figure 1.

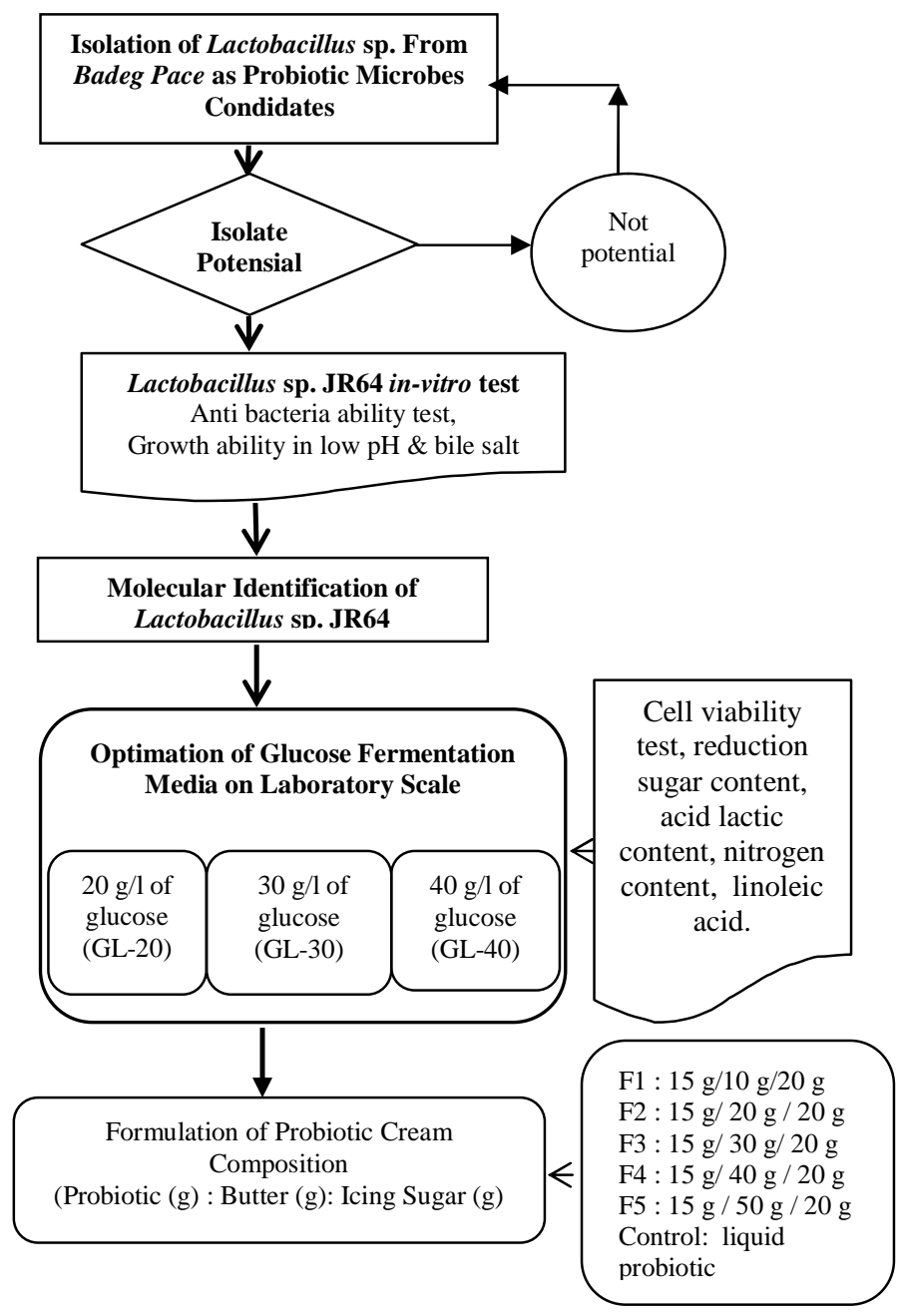

Figure 1. Stages of study

\section{RESULTS AND DISCUSSION}

\subsection{Isolation of Lactobacillus sp.}

The fermentation process carried out on laboratory scale using $250 \mathrm{ml}$ of glucose as carbon source consists of a three various concentration $(20 \mathrm{~g} / 1,30 \mathrm{~g} / 1,40 \mathrm{~g} / 1)$. The composition of the media with the content of micro elements such as: 5 g/ 1 sodium acetate, 2 $\mathrm{g} / 1$ ammonium acetate, $2 \mathrm{~g} / 1 \mathrm{Na} 2 \mathrm{HPO} 4,1 \mathrm{~g} / \mathrm{l}$ Tween 80, 0.1 $\mathrm{g} / \mathrm{MgSO} 4.7 \mathrm{H} 2 \mathrm{O}$ and $\quad 0.05 \mathrm{~g} / \mathrm{MnSO} 4.5 \mathrm{H} 1$, then the media plus up to $1,000 \mathrm{ml}$ of one liter water.

The results showed that Lactobacillus sp. Presented in ripe noni fruit were two isolates namely MMA and MMB; while the pace badeg obtained three isolates namely BPA, BPB and BPC. According to Sneath et al. (1986), the groups of lactic acid bacteria are rod-shaped having acatalase negative, gram-positive staining, and belonged to lactic acid bacteria of the genus Lactobacillus sp. The five isolates then were tested the ability of antibacterial and ability to grow in the gastrointestinal tract.

\subsection{In-vitro test of Lactobacillus sp.}

The results of lactic acid bacteria isolates ability against pathogenic bacteria showed that isolates from badeg pace had higher inhibitory power compared to isolates from ripe fruit noni. BPA has the highest antibacterial activity that was $3.9 \mathrm{~mm}$ to $4.0 \mathrm{~mm}$ in Escherichia coli ATCC 25922 and Staphylococcus aureus ATCC 25 923, almost similar to the control bacterial that was $4.0 \mathrm{~mm}$ and $4.2 \mathrm{~mm}$, whereas BPB isolates having inhibitory activity of $2.1 \mathrm{~mm}$ and $3.0 \mathrm{~mm}$ and BPC isolates has the inhibitory activity of $2.9 \mathrm{~mm}$ and $4.1 \mathrm{~mm}$. The isolates of MMA and MMB had very low antibacterial activities that were $1.0 \mathrm{~mm}$.

The results of ability test to grow on media containing bile salts showed that increasing bile salt concentration decreased isolates growth. Only three isolates that were $\mathrm{BPA}$ and $\mathrm{BPB}$, and $\mathrm{BPC}$ able to grow on media containing bile salts with a concentration of $1 \%$ to $10 \%$. This ability of these 3 isolates were lower than the control bacteria that growed up to $10 \%$ of bile salt. Bile is a surface active compounds that penetrates and reacts with the cytoplasmic membrane that is lipophilic which cause changes and damages to membrane structure.

Lactic acid bacteria in general have better resistance against membrane damage caused by the decreased of extracellular $\mathrm{pH}$. Differences susceptibility to membrane damage due to falling $\mathrm{pH}$ has been investigated by Bender et al.(1986), where membrane damage was measured based on the release of $\mathrm{Mg}$ ions from the cell. In strains that are less resistant to acid, $\mathrm{Mg}$ ions will be out of the cell when the $\mathrm{pH}$ reached 4, whereas in Lactobacillus casei membrane damage begin to occur at an external $\mathrm{pH}$ of less than 3 . 


\subsection{Molecular Identification of Lactobacillus sp. JR64}

Molecular identification of Lactobacillus sp was chosen from the best result of in vitro test that was Lactobacillus sp from badeg pace (CPA) and then named as Lactobacillus sp. JR64. Lactobacillus sp. JR64 was identified by using PCR that were expected to be in the $16 \mathrm{~S}$ rRNA.

\section{Isolation of Genomic DNA}

Genomic DNA extraction process carried out enzymatically by using Instagene matrix, it is a kit that can be used for the extraction of genomic DNA. This kit contains the components required in the process of extraction of the genome such as lysozyme, RNAse, and EDTA. RNAse serves to decompose the RNA, since the presence of RNA can contaminate DNA isolates. The presence of proteins in DNA isolates also can interfere with PCR amplification process, especially if the protein is a DNase that can decompose DNA. From this isolation process for $1360 \mathrm{ng}$ of DNA obtained with purity of (260/280) 2.5. The results of this isolation fulfilled as a DNA template, due to PCR amplification process took only 50-200 ng of DNA.

\section{PCR amplification of the 16S rRNA}

6S rRNA gene amplification was conducted using the primers $8 \mathrm{~F}$ and 1492R. Visualization of amplification results was conducted by agarose gel electrophoresis with a concentration of $1 \%$. Visualization results showed that amplicon fragment length obtained from the results of 16SrRNA PCR was estimated to approximately $1500 \mathrm{bp}$ based on the size of the ribbon on GeneRuler TM $1 \mathrm{~kb}$ DNA Ladder. These results indicated that the length of 16S rRNA gene amplicons with a prediction that is close to $1484 \mathrm{bp}$ when using primer $8 \mathrm{~F}$ and $1492 \mathrm{R}$.

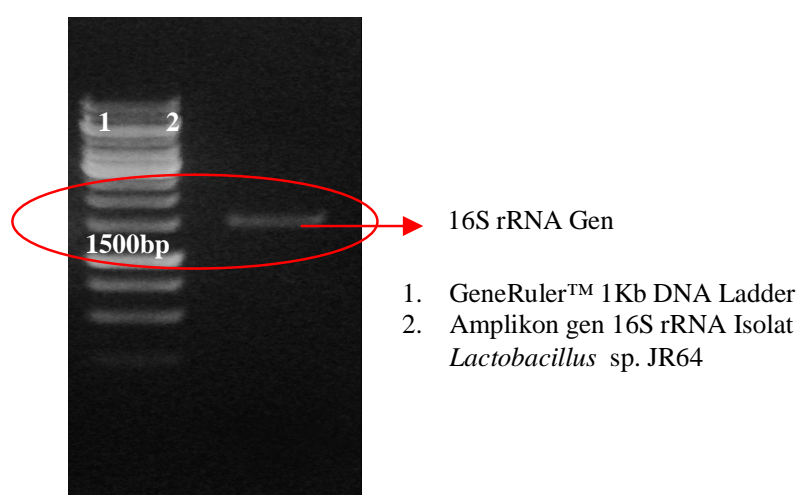

Figure 2. Result of 16S rRNA Gen amplification

\section{Determination of DNA Sequence $16 \mathrm{~S}$ rRNA region}

Determination of base sequences performed by PCR using the primers $765 \mathrm{R}$ and $1141 \mathrm{R}$ showed that base sequences of DNA fragment samples of Lactobacillus sp. JR64 using the ABI 3130 Genetic Analyzer is obtained as much as $945 \mathrm{bp}$.
The result of amplicon then compared it homology to sequencing bacterial genes contained in Genebank data, using BLAST-N program. The results of the BLAST nucleotide sequence of 16S rDNA data base contained in the site www.ncbi.com. Based on the analysis of alighment with the Clustal X program, the obtained phylogeneticfamily tree. Analysis showed that the isolates of Lactobacillus sp. JR64 has the highest similarity with Lactobacillus plantarum strain UK-3 with a similarity value of base pairs (max score) 854, the total value of base pairs (total score) 854 , the percentage of the overall analysis (query coverage) $100 \%$, the percentage of errors in the process (Evalue) is 0.0 and the percentage of accuracy of identification (identify max) 99\%. From the reading of the phylogenetic tree obtained result that isolates originating from badeg pace is a type of bacterium Lactobacillus plantarum JR64.

\section{Symbiosis between Glucose $(\mathrm{G})$ with the biomass $(\mathrm{X})$ and product $(P)$ in Omega-6 Fermentation}

To determine the interaction pattern between the use of substrates with the growth of $L$. plantarum JR 64 and product formation, it conducted analysis of residual sugar, the weighing of biomass, and amount of lactic acid and linoleic acid. Growth patterns of L. plantarum JR64 at glucose concentrations of $20 \mathrm{~g} / \mathrm{l}$ (GL-20) described in Figure 3.

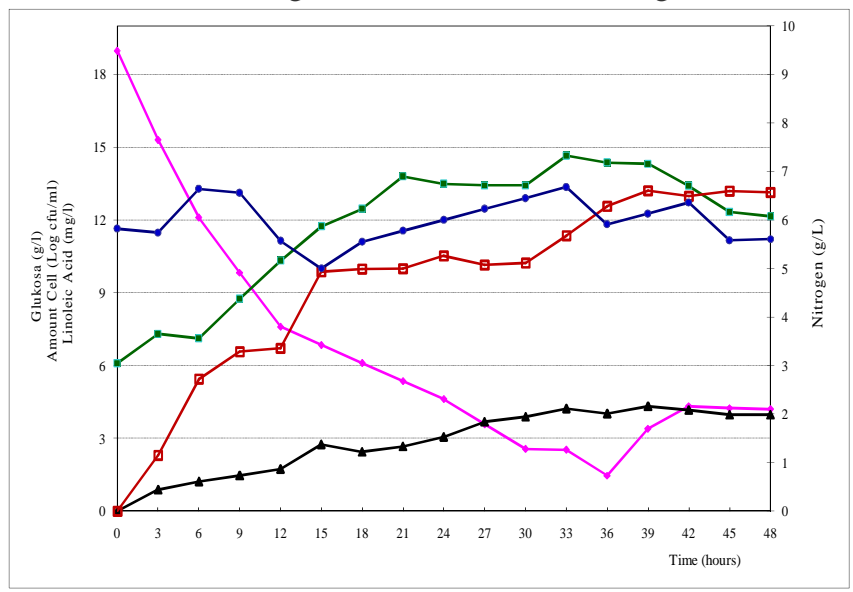

Figure 3. Relation between fermentation time and glucose consumption, number of cells, lactic acid and linoleic acid in glucose media GL-20 Symbol : : Glucose, $\mathbf{\square}:$ Cell amount, $\boldsymbol{\Delta}$ : lactic acid, $\square$ : linoleic acid, $\bullet$ Nitrogen

Figure 3 showed that the time lag occurs for 6 hours then changed exponentially up to 14 hours and also be the beginning of the stationary phase. The growth remained over when cultivation began walking for 30 hours and continued to decline until the end of cultivation. Substrate consumption of sugar as a source of carbon reduction on average in the interval time of 12 hours for all initial sugar concentration of $20 \mathrm{~g} /$ land $30 \mathrm{~g} / 1$ and $40 \mathrm{~g} / 1$, where microorganisms consumed sugar very rapidly as the energy source of growth; while consumption of nitrogen did not appear to have a linear pattern. But consumed in the reduction 
of volatile until the end of the third phase of exponential scale for the initial sugar concentration and afterwards L. plantarum JR64 consume less nitrogen. The trend for all three concentrations of product formation associated with the movement patterns of biomass formation. It can be concluded that the growth associated with the formation of the product. Cell growth and product formation by microorganism is a bioconversion process with micro and macro nutrient elements that are used during cultivation; sp that it will be biologically converted into biomass and metabolites. Each stage of bioconversion can be quantified by a coefficient (yield) that is expressed as the biomass formed per unit of substrate and product formed per unit substrate is denoted a $\mathrm{s} \mathrm{Y} \mathrm{x} / \mathrm{s}$ and $\mathrm{Y} \mathrm{p} / \mathrm{s}$.

Determination of $\mathrm{Y}$ /s s value could be calculated by the method of the linear regression between the amount of substrate (So-S) by the number of products produced (PPo) in each unit of time. According to Wang et al., (1979) yield the value of consumption of substrate for formation of product was calculated by empirical formula $(\mathrm{P}-\mathrm{Po})=\mathrm{Y}$ p/s $($ So-S $)$. Figure 4 showed how to compute $\mathrm{Y}$ p/s on a laboratory scale fermentation medium at the beginning of the media glucose $20 \mathrm{~g} / 1$ (Gl-20). In the same way, the value of $\mathrm{Y} \mathrm{p} / \mathrm{s}$ for the initial glucose concentration of $30 \mathrm{~g} / 1$ and $40 \mathrm{~g} / 1$ can be determined.

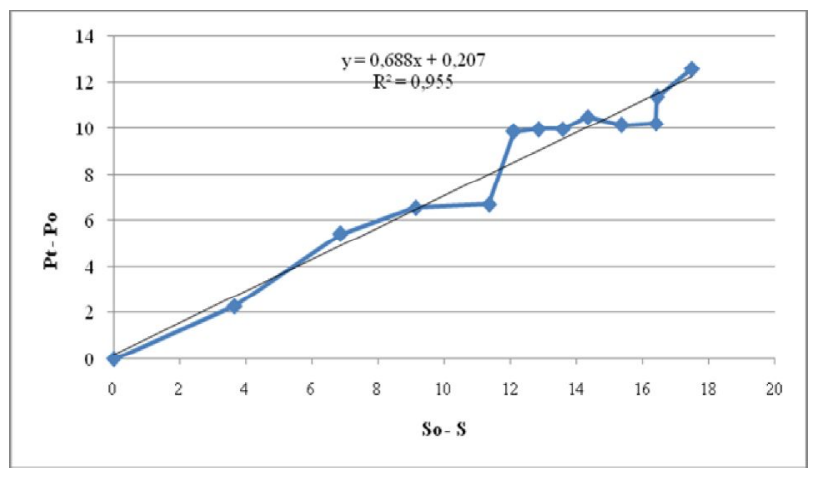

Figure 4. Relation between amount of substrat and amount of biomass product (X-Xo) in medium GL-20 per time unit.

The yield of substrate usage for biomass doubling of $\mathrm{Y} \mathrm{x} / \mathrm{s}$ is the ratio between the difference of biomass amount at $\mathrm{t}=\mathrm{t}$ by the amount of biomass at $\mathrm{t}=0$ (the difference between the amount of substrate at the beginning of cultivation with the rest of the substrate at time $t$ ). Value of $\mathrm{Y} x / \mathrm{s}$ can be determined by correlating between the amount of substrate use (So-S) and the amount of biomass formed (X$\mathrm{Xo})$. The slope of the regression equation of the line (X$\mathrm{Xo})=\mathrm{Y} \mathrm{x} / \mathrm{s}(\mathrm{So}-\mathrm{S})$ is the value of $\mathrm{Y} \mathrm{x} / \mathrm{s}$. Figure 5 showed how to calculate $\mathrm{Y} \quad \mathrm{X} / \mathrm{s}$ on a laboratory scale fermentation medium with initial glucose concentration of $20 \mathrm{~g} / \mathrm{l}$ values obtained YX/s: weight of $0.142 \mathrm{~g}$ cells $/ \mathrm{g}$ substrate or the equivalent of $14.2 \%$. In the same way the value for YX/s at GL-30 and GL-40 can be determined.

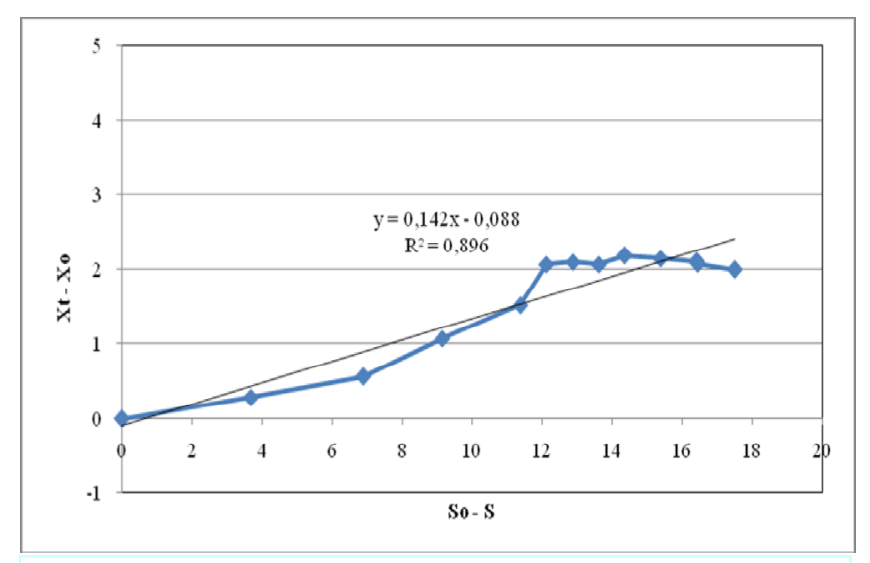

Figure 5. Relation between the amount of substrate usage (So-S) and the amount of biomass formed (X-Xo) on GL-20 medium per time unit.

The results of substrates usage efficiency to cell formation at glucose concentrations of $20 \mathrm{~g} / \mathrm{l}$ during 48 hours of fermentation only $\mathrm{Y} x / \mathrm{s}=14,2 \%$, while the substrate usage to produce linoleic acid was $\mathrm{Y}$ p/s $=68.8 \%$. Fermentation efficiency was highest at 24 hours that was $\mathrm{Yx} / \mathrm{s}=17.03 \%$ and $\mathrm{Y} \mathrm{p} / \mathrm{s}=74.72 \%$. In the same way, the efficiency of fermentation at glucose concentration of 30 $\mathrm{g} / \mathrm{l}$ for 48 hours was $\mathrm{Yx} / \mathrm{s}=70.7 \%$ and $\mathrm{Y} \mathrm{p} / \mathrm{s}: 9.2 \%$. Meanwhile, during the period up to 24 hours, it was obtain $\mathrm{Y}$ $\mathrm{x} / \mathrm{s}=41.6 \%$ and $\mathrm{Yp} / \mathrm{s}=9.3 \%$. The results of glucose fermentation of $40 \mathrm{~g} / \mathrm{l}$ obtained the value of $\mathrm{Y} \mathrm{x} / \mathrm{s}$ $=47.3 \%$ and $\mathrm{Y} / \mathrm{s}=7.5 \%$, whereas at 24 hours obtained $\mathrm{Y}$ $\mathrm{x} / \mathrm{s}: 27.3 \%$ and $\mathrm{Y} \mathrm{p} / \mathrm{s}: 5.86$.

\section{Design and Formulation of Probiotic Creamy Product}

Product design that became the target of this formulation was made in the form of a creamy product to obtain a sufficient length of cell viability and can be applied to various forms of food. Figure 6 showed the form of a cream formulation. Tests carried out cell viability for 28 days at refrigerant storage. The average number of bacteria from the five formulations up to 14 days increased, but began to decrease on day 21 and tended to continue to decreased up to day 28 .

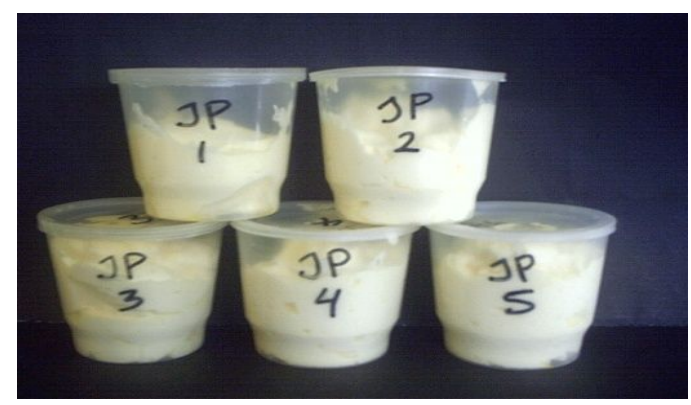

Figure 6. Formulation of Probiotic Cream

According to Tamime et al (1992), the shelf life of products at a refrigerant temperature is longer than the shelf life of product in room temperature, as a result of low activity of BAL in low temperature storage. Figure 7 indicated that the number of Lactobacillus plantarum JR64 cells of formula 
5 had the highest cell viability compared to other formulas. Formula 5 which contained 50 grams of butter, 20 grams of icing sugar, and 15 grams of probiotics have the suitability as probiotic medium.

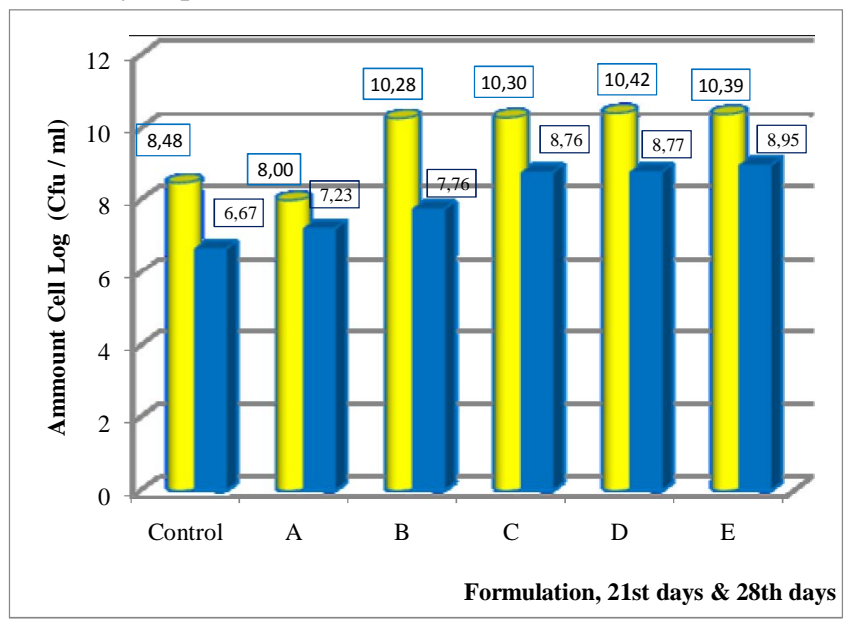

Figure 7. The amount of L. plantarum JR 64 of Probiotic Cream during 21 and 28 day storage

$$
\text { Symbol : }
$$$$
21^{\text {st }} \text { day, }
$$$$
\tau^{28^{\text {th }} \mathrm{day}}
$$

The average number of L. plantarum JR64 at the initial formulation ranges from from $10^{7} \mathrm{CFU} / \mathrm{ml}$ and after stored for 28 days the number of $L$. plantarum JR64 still met the requirements of the probiotic for formula 3, 4 and 5. The highest number of cells was the formula to-5: $\quad 8.95 \log \mathrm{CFU} / \mathrm{ml}$ or equal to $8.92 \mathrm{x}$ $10^{8} \mathrm{CFU} / \mathrm{ml}$.

\section{CONCLUSION}

From the results of this study, it could be concluded as follow.

1. Lactobacillus plantarum JR64 was the new isolates of lactic acid strains that was isolated from noni wine. $L$. plantarum JR 64 potential as probiotics, omega6 producing, and cholesterol lowering.

2. The highest yield $(\mathrm{Y} x / \mathrm{s}$ and $\mathrm{Y} \mathrm{p} / \mathrm{s})$ in the exponential phase for the fermentation of 24 hours was $17.03 \%$ and $74.72 \%$.

3. The best design and formulation for the cell viability of Lactobacillus plantarum JR64 was composed of $15 \mathrm{~g}$ of probiotic $50 \mathrm{~g}$ of butter 15 of g icing sugar, and number of cell during storage of the refrigerant temperature was $8.92 \times 10^{8} \mathrm{CFU} / \mathrm{ml}$.

\section{REFERENCES}

[1]. Association of Official Analytical Chemist (AOAC). 1984. Official Methods of Analysis. Washington DC.

[2]. Abasaeed AE, 1997. Sensetivity Analysis on a Sequencing Batch Reactor Model I Effect of Kinetic Parameters. J. Chem. Technol. Biotechnol. $70: 379-383$.

[3]. Amrane A, Prigent Y. 1999. Differentation of $\mathrm{pH}$ and free lactic acid effects on the various growth and production phases of Lactobacillus helveticus. J. Chem. Technol. 74 : 33-40.
[4]. Azcarate Peril MAA, Barcena JMB, Hassan HM, Klaenhammer TR. 2006. Transcriptional and function Analysis of Oxalyl-Coenzyme A (CoA) Decarboxylase and Formyl-CoA Transferase Genes from Lactobacillus acidhophilus. Appl. Environ. Microbiol. 72 (3) : 18911899.

[5]. Barefoot SF et al. 1994. Identification and Purification of a Protein That Induces Production of the Lactobacillus acidhophilus Bacteriocin Lactacin B. Appl. Environ. Microbiol. 60 (10) : 3522-3528.

[6]. Berry AR, Franco CMM, Zhang W, Middleberg APJ. 1999. Growth and lactic acid production in batch culture of Lactobacillus rhamnosus in a defined medium. Biotechnology Letters. 21 : 163-167.

[7]. Daniel C et al. 2006. Selecting Lactic Acid Bacteria for Their Safety and Functionality by Use of a Mouse Colitis Model. Appl. Environ. Microbiol. 72 (9) : 5799-5805.

[8]. Fardiaz, S. 1992. Mikrobiologi Pangan I. Kerjasama PAU Pangan dan Gizi IPB dan Gramedia Pustaka Utama, Jakarta

[9]. Fardiaz, S. 1989. Mikrobiologi Pengolahan Pangan Lanjut. PAU Pangan dan Gizi IPB, Bogor.

[10]. Frazier, W. C. and D. C. Westhoff. 1979. Food Microbiology $3^{\text {th }}$. McGraw-Hill Publishing Company Ltd., New York.

[11]. Ghosh R, Hardmeyer A, Thoenen I, Bachofen R. 1994. Optimization of the Sistrom Culture Medium for Large-Scale Batch Cultivation of Rhodospirillum rubrum under Semiaerobic Conditions with Maximal Yield of Photosynthetic Membranes. Appl. Environ. Microbiol. 60 (5) : 1698-1700.

[12]. Hang G, Block DE. 2009. Using Highly Efficient Nonlinear Experimental Design Methohds for Optimization of Lactococcus lactis Fermentation in Chemically Defined Media. Biotechnol. Prog. 25 (6) : 1587-1597.

[13]. Harris, D.C. 1995. Quantitative Chemical Analysis. $4^{\text {th }}$ edition. W.H. Freeman and Company, New York.

[14]. Kuhn K, Wonde B, Rabsch W, Reissbrodt R. 1994. Evaluation of Rambach Agar for detection of Salmonella Subspecies I to VI. Appl. Environ. Microbiol. 60 (2) : 749-751.Monteagudo JM, Aldavero M. 1999. Production of L-lactic acid by Lactobacillus delbrueckii in chemostat culture using an ion exchange resins system. $J$ Chem. Technol. Biotechnol. $74: 627-634$.

[15]. Nagao F, Nakayama M, Muto T, Okumura K. 2000. Effects of a Fermented milk Drink Containing Lactobacillus casei Strain Shirota on the immune System in Healthy Human Subjects. Biosci. Biotechnol. Biochem. 64(12) : 2706-2708.

[16]. Nelson, N. 1944. A Photometric Adaptation of the Somogyi Method for the Determination of Glucose. J. of Biological Chemistry. 153 (1) : 375 380 .

[17]. Zwietering MH, Wit JC, Cuppers HGAM, Riet K. 1994. Modeling of Bacterial Growth with Shifts in Temperature. Appl. Environ. Microbiol. 60 (1) : 204-213.

[18]. Zwietering MH, Cuppers HGAM, Wit JC, Riet K. 1994. Evaluation of Data Transformation and validation of a Model for the Effect of Temperature on Bacterial Growth. Appl. Environ. Microbiol. 60 (1) : 195-203.

[19]. Ohashi Y et al. 2002. Habitual Intake of Lactic Acid Bacteria and Risk reduction of Bladder Cancer. Urologia Internationalis. $68: 273-280$.

[20]. Ohashi R, Yamamoto T, Suzuki T. 1999. Continuous Production of Lactic Acid from Molasses by Perfusion Culture of Lactococcus lactis Using a Strired Ceramic Membrane Reactor. J. Biosci. Bioeng. 87 (5) : 647-654.

[21]. Okada S, Iwamatu S. 1997. Scale-up Production of Milbemcin by Stretomyces higroscopicus subsp. Aureolacrimosus with Control of Internal Pressure, Temperature, Aeration and Agitation. J. Chem. Technol. Biotechnol. $70: 179-187$.

[22]. Ooijkaas LP, Wilkinson EC, Tramper J, Buitelaar RM . 1999. Medium Optimization for Spore Production of Coniothyrium minitans Using Statistically-Based Experimental Designs. Biotechnologi and Bioengineering. 64 (1) : 92-100.

[23]. Osada K et al. 1998. Dietary Oxidized Cholesterol Modulates Cholesterol Metabolism and Linoleic Acid Desaturation in Rats Fed High-Cholesterol Diets. Lipids. 33 (8) : 757-764.

[24]. Passos V et al., 1994. Kinetics and Modeling of Lactic Acid Production by Lactobacillus plantarum. Appl. Environ. Microbiol. 60 (7) : 26272636 
[25]. Ren PR, Yu RC, Chou CC, Tsai YH. 2002. Antimutagenic Activity of Several Probiotic Bifidobacteria againts Benzoa (a) pyrene. J. Biosci. Bioeng. 94 (2) : 148-153.

[26]. Saarela M et al. 2000. Probiotic bacteria : safety, functional and technological properties. Journal of Biotechnology. 84 : ( 197-215.

[27]. Scragg, A.H. 1991. Bioreactors in Biotechnology : a practical approach. Ellis Horwood, LTD. England.

[28]. Speck, M. L. 1978. Development in Industrial Microbiology. Dalam Economic Microbiology Fermented Food Vol. VII. Academic Press, London.

[29]. Sugiyama K, Yamakawa A, Saeki S. 1997. Correlation of suppressed Linoleic Acid Metabolism with the Hypocholesterolemic Action of Eritadenine in Rats. Lipids. 32 (8) : 859-866

[30]. Somoggyi, M. 1952. Notes on Sugar Determination. J. of biological Chemistry. $195: 19-23$.

[31]. Sreekumar O, Hosono A. 2000. Immediate Effect of Lactobacillus achidophilus on the Intestinal Flora and Fecal Enzymes of rats and the in Vitro Inhibition of Escherichia coli in Coculture. Journal of Dairy Science. 83 (5) : 932-939.
[32]. Sreenath HK, Moldes AB, Koegel RG, Straub R J. 2001. Lactic Acid Production by Simultaneous Saccharification and Fermemtation of Alfalfa Fiber. J. Biosci. Bioeng. 92 (6) : 518-523.

[33]. Tannock G W, Tangerman A, Schaik AV, McConnel M A.1994. Deconjugation of Bile Acids by Lactobacilli in the Mouse Small Bowel. Appl. Environ. Microbiol. 60 (9) : 3419-3420.

[34]. Shioya S, Shimizu K, Yoshida T. 1999. Knowledge-Based Design and Operation of Bioprocess Systems. J. Biosci. Bioeng. 87 (3) : 261-266.

[35]. Tunga R, Banerjee R, Bhattacharyya BC. 1999. Optimization of $n$ Variable Biological Experiments by Evolutionary Operation Factorial Desighn Technique. J. Biosci. Bioeng. 87 (2) : 224-230.

[36]. Valerio F et al. 2006. In Vitro and in Vivo Survival and Transit Tolerance of Potentially Probiotic Strains Carried by Arthchokes in the Gastrointestinal Tract. Appl. Environ. Microbiol. 72 (4) : 3042-3045.

[37]. Wegkamp A, Teusink B, De Vos WM, Smid EJ. 2010. Development of a minimal growht medium for Lactobacillus plantaraum. Letters in Applied Microbiology. 50 : 57-64.

[38]. Yoo IK et al., 1997. Effect of B Vitamin Supplementation on Lactic Acid Production by Lactobacillus casei. J. Ferment. Bioeng. 84 (2) : 172-175. 